2011-04-01

\title{
Identification of 'Carbon Hot-Spots' and Quantification 1 of GHG Intensities in the Biodiesel Supply Chain using Hybrid LCA and Structural Path Analysis
}

\author{
Adolf Acquaye \\ University of York, adolf.acquaye@york.ac.uk \\ Thomas Wiedmann \\ University of York \\ Kuishang Feng \\ University of Leeds
}

See next page for additional authors

Follow this and additional works at: https://arrow.tudublin.ie/dubenart

Part of the Bioresource and Agricultural Engineering Commons, Environmental Engineering Commons, Natural Resource Economics Commons, Natural Resources Management and Policy Commons, Oil, Gas, and Energy Commons, and the Sustainability Commons

\section{Recommended Citation}

Acquaye, A. et al (2011). Identification of 'Carbon Hot-Spots' and Quantification of GHG Intensities in the Biodiesel Supply Chain Using Hybrid LCA and Structural Path Analysis. Environmental

Science\&Technology, vol. 45, no.6, pp 2471-2478. doi:10.1021/es103410q

This Article is brought to you for free and open access by the Dublin Energy Lab at ARROW@TU Dublin. It has been accepted for inclusion in Articles by an authorized administrator of ARROW@TU Dublin. For more information, please contact arrow.admin@tudublin.ie, aisling.coyne@tudublin.ie,gerard.connolly@tudublin.ie.

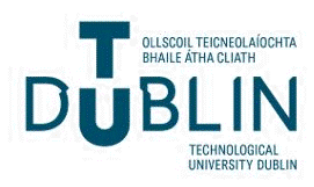




\section{Authors}

Adolf Acquaye, Thomas Wiedmann, Kuishang Feng, Robert Crawford, John Barrett, Johan Kuylenstierna, Aidan Duffy, Lenny Koh, and Simon McQueen-Mason 
Acquaye et al. (2011) Identification of 'Carbon Hot-Spots' and Quantification of GHG Intensities in the Biodiesel Supply Chain Using Hybrid LCA and Structural Path Analysis. Environ. Sci. Technol.,, 45 (6), pp 2471-2478

\section{Identification of 'Carbon Hot-Spots' and Quantification of GHG Intensities in the Biodiesel Supply Chain using Hybrid LCA and Structural Path Analysis}

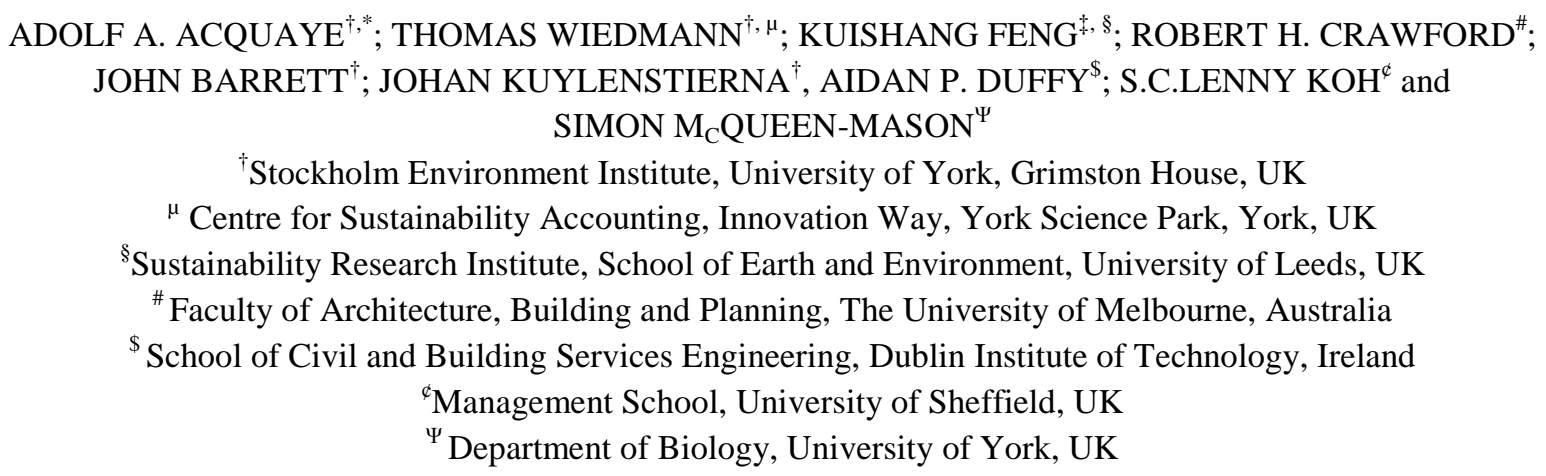

Corresponding Author: Tel.: +441904322893; Fax: +441904322898; Email: adolf.acquaye@ york.ac.uk

\section{Abstract}

It is expected that biodiesel production in the EU will remain the dominant contributor as part of a $10 \%$ minimum binding target for biofuel in transportation fuel by 2020 within the $20 \%$ renewable energy target in the overall EU energy mix. Life cycle assessments (LCA) of biodiesel to evaluate its environmental impacts have, however, remained questionable, mainly because of the adoption of a traditional process analysis approach resulting in system boundary truncation and because of issues regarding the impacts of land use change and $\mathrm{N}_{2} \mathrm{O}$ emissions from fertiliser application. In this study, a hybrid LCA methodology is used to evaluate the life cycle $\mathrm{CO}_{2}$ equivalent emissions of rape methyl ester (RME) biodiesel. The methodology uses input-output analysis to estimate upstream indirect emissions in order to complement traditional process LCA in a hybrid framework. It was estimated that traditional LCA accounted for $2.7 \mathrm{~kg} \mathrm{CO}_{2}$-eq per $\mathrm{kg}$ of $\mathrm{RME}$ or $36.6 \%$ of total life cycle emissions of the RME supply chin. Further to the inclusion of upstream indirect impacts in the LCA system (which accounted for $23 \%$ of the total life cycle emissions), emissions due to direct land use change (6\%) and indirect land use change (16.5\%) and $\mathrm{N}_{2} \mathrm{O}$ emissions from fertiliser 
Acquaye et al. (2011) Identification of 'Carbon Hot-Spots' and Quantification of GHG Intensities in the Biodiesel Supply Chain Using Hybrid LCA and Structural Path Analysis. Environ. Sci. Technol.,, 45 (6), pp 2471-2478

31 applications (17.9\%) were also calculated. Structural path analysis is used to decompose upstream indirect emissions paths of the biodiesel supply chain in order to identify, quantify and rank high carbon emissions paths or 'hot-spots' in the biodiesel supply chain. It was shown, for instance, that inputs from the 'Other Chemical Products' sector (identified as phosphoric acid, $\mathrm{H}_{3} \mathrm{PO}_{4}$ ) into the biodiesel production process represented the highest carbon emission path (or hot-spot) with $5.35 \%$ of total upstream indirect emissions of the RME biodiesel supply chain.

\section{Introduction}

There has been a growing interest in the use of biofuels as a sustainable replacement for fossil fuels over recent years. This has led to many countries, including the UK and the wider EU community, formulating policies that set out long-term strategies to promote biofuel production and use driven mainly by policy goals such as: reducing greenhouse gas emissions through the decarbonisation of transport fuels, diversifying fuel supply sources and developing long-term replacements for fossil oil. The EU has a long-term vision for biofuels, proposing that by 2030 and beyond, clean and $\mathrm{CO}_{2}$-efficient biofuels would make up $25 \%$ of the EU's transport fuel needs [1]. Refer to Figure S1 in the Supporting Information (SI) on the web for an illustration of the transition plan of past EU policies affecting biofuels and the timescale for future commitments.

50 Biodiesel is Europe's dominant renewable fuel [2] with rapeseed accounting for about $80 \%$ of primary feedstock for biodiesel processing and about $75 \%$ share of total oilseed production of EU-27 in 2009-10 [3]. Production of biodiesel on an industrial scale began in 1992 about 
Acquaye et al. (2011) Identification of 'Carbon Hot-Spots' and Quantification of GHG Intensities in the Biodiesel Supply Chain Using Hybrid LCA and Structural Path Analysis. Environ. Sci. Technol.,, 45 (6), pp 2471-2478

53 five years before the EU's Energy White Paper 'Energy for the Future', driven mainly by

54 positive signals in terms of support from member states and the EU Commission. Figure S2

55 under SI on the web shows the trend in the growth of biodiesel in the EU since 1992.

56 Despite the potential growth and benefits of biofuels, many research findings have raised

57 arguments against them in a global context. The Food and Agricultural Organisation [4]

58 acknowledges that, although biofuels under certain conditions help reduce greenhouse gas

59 emissions (GHG), the global effects of an expansion of biofuel production will depend

60 crucially on where and how feedstocks are produced. It is therefore anticipated that the more

61 sustainable second-generation biofuels produced from non-food crops and residues can

62 provide the best opportunity for the commercial viability and development of the sector from

632014 onwards [5]. Lifecycle assessment (LCA) of second-generation bioethanol produced

64 from surplus forest-bioenergy resources in Norway for example was estimated to potentially save $6-8 \%$ of Norway's global warming GHG emissions associated with road transportation [6]. The accelerating use of biomass including, cereals such as wheat, maize, sugar and

67 oilseed for biofuel and power generation has come about because of positive government directives and political decisions [7]. However, the exact impact on the resource base and the

69 environment due to the demand for biofuels is unknown.

70 Many authors have therefore undertaken studies to evaluate the environmental impacts of 71 biofuel production [8-10]. These studies have mainly used traditional LCA methods based on 72 ISO 14040 and mostly involved comparative studies with traditional fossil fuel production

73 [11]. Traditional LCA of biofuel production involves setting a system boundary for the 
Acquaye et al. (2011) Identification of 'Carbon Hot-Spots' and Quantification of GHG Intensities in the Biodiesel Supply Chain Using Hybrid LCA and Structural Path Analysis. Environ. Sci. Technol.,, 45 (6), pp 2471-2478

74 biofuel supply chain and using process analysis data to estimate the carbon impacts of selected supply chains within the system boundary.

It is, however, well recognised that because of difficulties in collecting process-specific data in LCA and the infinite number of possible supply chain paths, the use of hybrid LCA provides a more comprehensive framework for the evaluation of environmental impacts of upstream production [12-15]. A hybrid LCA combines the specificity of process analysis with the extended system boundary of input-output (IO) analysis. Hybrid LCA has had many applications. Lenzen and Wachsmann [16] and Crawford [17] demonstrated the use of a hybrid LCA technique in the assessment of the energy content of wind turbines in order to achieve system completeness. A limited number of studies using hybrid LCA have been undertaken on biofuels. Bright et al. [18] undertook an environmental assessment of woodbased biofuel to estimate the cumulative global warming mitigation under different scenarios in Norway. The hybrid LCA in this study consisted of a two-region (Norway and the European Union) IO model and process analysis inventory for the biofuel options.

In this paper the life cycle GHG emissions of a typical biodiesel supply chain are calculated using hybrid LCA, incorporating process-specific data of rape methyl ester (RME) production and inputs from higher upstream processes such as chemical inputs, mining, transportation, banking, equipment, etc, based on input-output analysis. Direct and indirect emissions in the biofuel supply chain are determined, including direct and indirect land use change and $\mathrm{N}_{2} \mathrm{O}$ emissions from fertiliser application. Furthermore, structural path analysis (a decomposition technique used in economic and ecological systems analysis) is applied to identify, quantify and rank high carbon emission paths - or 'carbon hot-spots' - in the supply 
Acquaye et al. (2011) Identification of 'Carbon Hot-Spots' and Quantification of GHG Intensities in the Biodiesel Supply Chain Using Hybrid LCA and Structural Path Analysis. Environ. Sci. Technol.,, 45 (6), pp 2471-2478

chain. Some studies have demonstrated the use of SPA as a decomposition technique of environmental impacts in a LCA context [19-20]. To the best of the authors' knowledge, this is the first time that SPA has been used for an analysis of the biodiesel supply chain. This detailed analysis is aimed at helping to tailor and prioritise mitigation efforts through the use of biofuels.

101

\section{Material and Methods}

104 'Integrated hybrid LCA' as defined by Suh and Huppes [21] is applied in this study. This form of hybrid LCA combines a process matrix and an IO matrix in a consistent mathematical framework [22]. Whereas the process component systematically computes physical inputs and outputs of each production step within the system boundary, the input-output component completes the analysis by enumerating upstream indirect inputs from outside the process system boundary.

110 For an integrated hybrid assessment of biofuel supply chains, the process matrix is linked to

111 the input-output matrix using the operational expenditure of biofuel production to account for

112 upstream inputs. As shown by Suh and Huppes [21], the general relationship for the integrated hybrid model is given in matrix notation by:

$$
\widetilde{\mathbf{P}}_{\text {hybrid }}=\left[\begin{array}{cc}
\mathbf{E}_{\mathbf{p}} & \mathbf{0} \\
\mathbf{0} & \mathbf{E}_{\mathbf{i}-\mathbf{o}}
\end{array}\right]\left[\begin{array}{cc}
\mathbf{A}_{\mathbf{p}} & -\mathbf{D} \\
-\mathbf{U} & \left(\mathbf{I}-\mathbf{A}_{\mathbf{i}-\mathbf{o}}\right)
\end{array}\right]^{-\mathbf{1}}\left[\begin{array}{l}
\mathbf{y} \\
\mathbf{0}
\end{array}\right] \quad \text { (Equation 1) }
$$

\section{Where:}




\section{Please cite this paper as:}

Acquaye et al. (2011) Identification of 'Carbon Hot-Spots' and Quantification of GHG Intensities in the Biodiesel Supply Chain Using Hybrid LCA and Structural Path Analysis. Environ. Sci. Technol.,, 45 (6), pp 2471-2478

$116 \widetilde{\mathrm{P}}_{\text {hybrid }}=$ Total (direct and indirect) environmental impact (e.g. $\mathrm{CO}_{2}$-eq emissions) associated 117 with one unit of final demand $y$ for the product (here biodiesel).

$118 \quad \mathrm{~A}_{\mathrm{p}} \quad=$ square matrix representation of process inventory, $($ dimension:s $\times \mathrm{s})$

$119 \quad \mathrm{~A}_{\mathrm{i}-\mathrm{o}} \quad=\mathrm{IO}$ technology coefficient matrix $($ dimension: $\mathrm{m} \times \mathrm{m})$

120 I = identity matrix $($ dimension: $\mathrm{m} \times \mathrm{m})$

$121 \mathrm{U}=$ matrix representation of upstream cut-offs to the process system (dimension:m $\times \mathrm{s})$

122 D = matrix of downstream cut-offs to the process system (dimension:s $\times \mathrm{m})$

$123 \mathrm{E}_{\mathbf{p}}=$ process inventory environmental extension matrix. $\mathrm{CO}_{2}$-eq emissions are 124 diagonalised (dimension: $\mathrm{m} \times \mathrm{s}$ )

$125 \mathrm{E}_{\mathbf{i}-\mathbf{o}}=\mathrm{IO}$ environmental extension matrix. $\mathrm{CO}_{2}$-eq emissions are diagonalised $($ dimension: $\mathrm{m} \times \mathrm{s})$

$\left[\begin{array}{l}\mathbf{y} \\ \mathbf{0}\end{array}\right]=$ Functional unit column matrix with dimension $(\mathrm{s}+\mathrm{m}, 1)$ where all entries are $\mathbf{0}$ except $y$

129 Matrix $A_{p}$ describes the product inputs into processes as captured in the unit process

130 exchanges (or process analysis inventory from ecoinvent in this case) and described in Table

131 S1. These processes, together with the sectoral inputs from IO sectors, are used to draw up

132 the biodiesel supply chain map as depicted in Figure S3.

133 Matrix $U$, which is assigned a negative sign, represents the higher upstream inputs from the

134 IO system to the process system. Matrix $D$, also assigned a negative sign, represents the 


\section{Please cite this paper as:}

Acquaye et al. (2011) Identification of 'Carbon Hot-Spots' and Quantification of GHG Intensities in the Biodiesel Supply Chain Using Hybrid LCA and Structural Path Analysis. Environ. Sci. Technol., 45 (6), pp 2471-2478

135 (downstream) use of goods / process inputs from the process to the background economy (IO

136 system). As explained by Suh and Huppes [21], the downstream cut-off matrix represents the

137 link from the process-based (foreground) system to the IO-based (background) system. It can

138 be argued that the downstream cut-off flows in $D$ are often small compared to the - normally

139 much larger - background economy (cf.[23]). The aim of the present paper is to quantify the

140 total emissions of biodiesel production in the status-quo economy of the UK in 2004 when

141 the market share of biodiesel as a percentage of road transport fuel was at a modest $0.09 \%$ in

1422004 [24]. For the sake of simplification we therefore neglect interactions with the

143 background economy and set values in $D$ are set to zero. We acknowledge, however, that a

144 more general use of biodiesel in the economy would ideally be evaluated by including

145 industries' expenditures on biodiesel in $D$ (e.g. by assuming different market penetrations of

146 biodiesel in a number of scenarios).

147 The final demand $\widetilde{\boldsymbol{y}}$ for biodiesel also represents the functional unit of the LCA system, set to

$148 \quad 1 \mathrm{~kg}$ of RME biodiesel in this study.

149 In order to achieve a complete LCA system for the biodiesel supply chain, upstream cut-offs

150 from the process-based LCA system were estimated using input-output analysis. For 151 example, to estimate the contributions of an upstream service (for example: administration)

152 for a given process inventory (for example: electricity) already captured in the process

153 matrix, $\mathbf{A}_{\mathbf{p}}$ the following steps were taken. The unit cost of the process under consideration

154 (example: electricity) was obtained [£/kWh]. This was multiplied by the input (in physical

155 terms) of electricity $[\mathrm{kWh}]$ obtained from the process matrix. The results, $k$ (that is: $156[£ / \mathrm{kWh}]^{*}[\mathrm{kWh}]$ ) represents the amount of electricity (in $£$ ) needed to produce $1 \mathrm{~kg}$ of final 
Acquaye et al. (2011) Identification of 'Carbon Hot-Spots' and Quantification of GHG Intensities in the Biodiesel Supply Chain Using Hybrid LCA and Structural Path Analysis. Environ. Sci. Technol.,, 45 (6), pp 2471-2478

157 demand of biodiesel. This amount is then used as a scalar multiplier to the column $a_{i j}$ of the

158 IO technology matrix, $A_{i-o}$ where $j$ corresponds to the Electricity industry. To avoid double

159 counting, all inputs already captured in the process matrix are discounted from the resulting

160 column vector $k a_{i j}$. The corrected values $k a_{i j} *$ become elements of the upstream input

161 matrix $U$. The administrative expenditure linking the process LCA electricity to the IO table

162 corresponds to $k a_{i j}$ where $i$ corresponds to Administration as a product and $j$ Electricity as 163 an industry. Refer to Spreadsheet S1.

164 Uncertainty in upstream emissions was estimated by including the maximum/minimum IO upstream cut-offs into the LCA system. To account for the maximum IO upstream cut-offs, all potential sectoral products that are indirect input requirements into biodiesel production

167 are included. Similarly, to account for minimum IO upstream cut-offs, only sectoral products that are highly probable indirect input requirements into biodiesel production supply chain are included. Refer to the supplementary Spreadsheet S1 for inputs into the upstream supply chain for the maximum and minimum case scenarios. Besides its mathematical consistency, integrated hybrid LCA provides a comprehensive framework because all inputs associated with the biodiesel supply chain can be expressed by the combination of process and IO 173 matrices.

\subsection{Structural Path Analysis}

176 Taylor's series expansion is applied only to the IO part of Equation (1) because the inputs of

177 the unit process obtained from ecoinvent are clearly known: 
Acquaye et al. (2011) Identification of 'Carbon Hot-Spots' and Quantification of GHG Intensities in the Biodiesel Supply Chain Using Hybrid LCA and Structural Path Analysis. Environ. Sci. Technol.,, 45 (6), pp 2471-2478

179 EIy', represents the direct GHG emissions emitted (at production level 0) for a given demand 180 and $E A^{\mathrm{n}} \mathrm{y}$ the indirect GHG emissions emitted for a given final demand at the $n^{\text {th }}$ production

181 level. The Taylor series expansion of the Leontief inverse matrix can be further decomposed

182 by unravelling the $A$ matrix (or the IO technology coefficient matrix with elements, $a_{i j}$ ) into 183 a series of structural paths at the $n^{\text {th }}$ order to systematically identify important supply chains

184 [25]. Summing up across all products $i$ and industries, $j$, the total environmental impact of a 185 final demand bundle $y_{i}$ can be decomposed into: (Equation 3)

$$
P_{\mathrm{IO}}=\sum_{i=1}^{\mathrm{n}} \sum_{\mathrm{j}=1}^{\mathrm{n}} e_{j}\left(I_{j i}+a_{j i}+\sum_{k=1}^{n} a_{j k} a_{k i}+\sum_{l=1}^{n} \sum_{k=1}^{n} a_{j l} a_{l k} a_{k i}+\cdots\right) \mathrm{y}_{\mathrm{i}}
$$

186

where $e_{j}$ is the emission intensity of industry $j$ and elements $a_{n m}$ represent transaction coefficients between sector $n$ and $m$. Each multiplied term represents the contribution of an individual supply chain path. In the case of biodiesel in this study, the emission "carbon hot spots' in the supply chain were to be identified and therefore the combined upstream inputs from matrix $U$ as the demand bundle $y_{i}$ were used: (Equation 4)

$$
y_{i}=\sum_{j=1}^{n} k a_{i j} *
$$

193 Where $k$ represents the $£$ equivalent needed by industry $j$ to produce $1 \mathrm{~kg}$ of biodiesel. 
Acquaye et al. (2011) Identification of 'Carbon Hot-Spots' and Quantification of GHG Intensities in the Biodiesel Supply Chain Using Hybrid LCA and Structural Path Analysis. Environ. Sci. Technol.,, 45 (6), pp 2471-2478

194 The decomposition of the series expansion can be represented as a tree diagram (Refer to

195 Figure S4) whereby each tier in the tree represents a different production layer and each node

196 gives the contribution to total environmental impacts from the demand, $y$ [26].

197 Production layer refers to the stage of supply to the main product. Production layer 0

198 therefore refers to the biodiesel production process. Production layer 1 is the first stage of the

199 upstream supply chain and production layer 2, is the supplier to the first upstream supplier of

200 the biodiesel process. In a SPA disaggregation of a product system, each node represents a

201 contribution to the total environmental impacts from the demand, $y$.

202 The maximum number of nodes at a production level is given by:

203 Number of Nodes $=n^{l+1}$

(Equation 5)

$204 n=$ Number of sectors in the economy

$1=$ Production level

206 The importance of supply chain decomposition in disentangling upstream emission paths in a product system is evident in the fact that upstream environmental impacts are often greater than direct environmental impacts in a supply chain. In a carbon footprint case study of economic sectors in Australia and the US, Huang et al. [27] for example, showed that direct

210 emissions of the majority of sectors are below $20 \%$ of the total carbon footprint, and can be

211 as low as $1 \%$. To maximise the potential for biodiesel to achieve real $\mathrm{CO}_{2}$ emissions

212 reductions compared to fossil fuels, high emissions intensity paths or 'hot-spots' in the supply

213 chain must be identified and possible lower emission alternative processes for the production

214 of biofuels must be found. 
Acquaye et al. (2011) Identification of 'Carbon Hot-Spots' and Quantification of GHG Intensities in the Biodiesel Supply Chain Using Hybrid LCA and Structural Path Analysis. Environ. Sci. Technol.,, 45 (6), pp 2471-2478

\subsection{Process Analysis Data}

217 The 2010 ecoinvent database v2.2 was used to compile the process analysis life cycle

218 inventory described as unit process exchanges. This dataset includes production of biodiesel

219 rape methyl ester (RME) from rape oil from esterification plants in the EU. The operation of storage tanks and fuel stations, including the distribution to the final consumer and all necessary transport requirements are included. Emissions arising from evaporation and treatment of effluents (may also refer to the air emissions of the plant) are also included. For the analysis, corresponding $\mathrm{CO}_{2}$-eq emissions data of unit process exchanges, $E$, emitted in producing $1 \mathrm{~kg}$ of $\mathrm{RME}$ biodiesel were determined. Biogenic $\mathrm{CO}_{2}$ was captured in the unit process exchanges obtained from ecoinvent [28]. It was calculated using the principle of carbon balance (input of carbon = output of carbon); that is, the uptake of carbon during plant growth plus all inputs of biogenic carbon with all pre-products minus biogenic carbon emissions should equal the biogenic carbon content of the biofuel or the product after all allocations have been done [28]. The unit process exchanges representing the process analysis data from ecoinvent are presented as Table S1 as part of Supplementary Information

231 on the web.

\subsection{Input-Output (IO) Analysis Data}

234 Previously constructed 2004 UK domestic and UK imports supply and use tables

235 disaggregated to 178 sectors were used to derive the input-output data used in the study [29]. 


\section{Please cite this paper as:}

Acquaye et al. (2011) Identification of 'Carbon Hot-Spots' and Quantification of GHG Intensities in the Biodiesel Supply Chain Using Hybrid LCA and Structural Path Analysis. Environ. Sci. Technol., 45 (6), pp 2471-2478

236 Wiedmann et al. [29] describe the construction of a multi-regional input-output (MRIO)

237 model using UK national IO tables and rest-of-world (ROW) tables from the Global Trade

238 Analysis Project (GTAP). A technology coefficients matrix was derived for both the UK

239 domestic and UK imports use table. For the purpose of the present study, the ROW economy

240 is represented as one symmetric table (technical details of this 2-region model have been

241 described in [30].

242 Columns of UK and ROW industry input requirements are augmented with data for

243 greenhouse gas emissions to derive sectoral emissions intensities $\left(\mathrm{kg} \mathrm{CO}_{2}\right.$-eq/£) for the

244 environmental matrix, $E_{i-o}$. A supply chain map illustrating the comprehensive system

245 boundary framework of the biodiesel supply chain adopted in this study is available in Figure

246 S3 under SI on the web.

\subsection{Allocation Factors}

249 The production of RME results in multiple product outputs. For example, the processing of 250 oil mill into rape oil also results in the production of rape mill as a by-product. The 251 esterification of vegetable oil into RME also produces glycerine and potassium sulphate. In 252 order to deal with multiple product outputs, LCA studies apply the method of either 253 allocation or system expansion. In the first case, inventory data are allocated to the main 254 product, by-products and waste, respectively, in order to assign material inputs and environmental impact. In system expansion, the boundary is extended to account for the input and output flows of all products. In this study, we use the first option, allocation, as we are specifically interested in the provision of biodiesel. 


\section{Please cite this paper as:}

Acquaye et al. (2011) Identification of 'Carbon Hot-Spots' and Quantification of GHG Intensities in the Biodiesel Supply Chain Using Hybrid LCA and Structural Path Analysis. Environ. Sci. Technol., 45 (6), pp 2471-2478

258 Allocation factors can be based either on mass flow, energy value or economic revenue of coproducts. Economic allocation has been established as a recognised way of systematically executing allocation in LCA [31-33]. The International Standards Organisation [34] also gives this allocation option in Step 3 of its allocation procedure. Hence, in this study, the economic revenue allocation as adopted in ecoinvent [28] was used. To reduce the uncertainty related to economic allocation because of potential fluctuations in the economic values of product and co-products, the environmental burdens are allocated according to the revenue of all process products, based usually on the average prices for three consecutive years. (Refer to Table S2 for allocation details). Allocation factors for other methods related to the production of RME are also presented in ecoinvent [28].

\section{Results and Discussions}

\subsection{Hybrid Life Cycle $\mathrm{CO}_{2}$-eq of Biodiesel Production}

271 The total emissions of all unit process exchanges representing the process analysis data of the biodiesel production process is $2.7 \mathrm{~kg} \mathrm{CO}_{2}$-eq or $36.6 \%$ of the total life cycle emissions. IO upstream indirect emissions (for the base case impact scenario) account for $1.7 \mathrm{~kg} \mathrm{CO}_{2}$-eq of the total life cycle emissions. Upstream emissions include embodied emissions such as those associated with utilities, equipments, chemicals, mining, construction of buildings, maintenance, services such as banking and finance, insurance, research and development, advertising, etc., and accounted for approximately $23 \%$ of total emissions. A further breakdown of these emissions is provided in Section 3.3 (Structural Path Analysis of 
Acquaye et al. (2011) Identification of 'Carbon Hot-Spots' and Quantification of GHG Intensities in the Biodiesel Supply Chain Using Hybrid LCA and Structural Path Analysis. Environ. Sci. Technol.,, 45 (6), pp 2471-2478

280 It was also estimated (from the process analysis inventory in ecoinvent) that the esterification

281 of vegetable oil to RME process accounted for $35.5 \%$ of the total emissions or $97 \%$ of

282 emissions due to the unit process exchanges in the process inventory. The other unit process

283 exchanges: road and train transport, electricity supply, regional distribution of oil, waste

284 management and water treatment from the process analysis inventory in ecoinvent

285 collectively accounted for around $1.1 \%$ of the total emissions associated with the RME

286 biodiesel production process.

\subsection{Other Impacts}

It has generally been argued that greenhouse gas releases from land use change and nitrous oxide $\left(\mathrm{N}_{2} \mathrm{O}\right)$ emissions from the use of fertilisers can potentially be significant enough to

291 change the environmental profile of biodiesel [35-36].

292 With $\mathrm{N}_{2} \mathrm{O}$ having a global warming potential 298 times that of $\mathrm{CO}_{2}$ when considered over a

293 100-year period [37], the use of nitrogen fertilisers has the potential to significantly affect the

294 GHG emissions balance of biodiesel. $\mathrm{N}_{2} \mathrm{O}$ is emitted both directly from soils due to the use of

295 nitrogen-based fertilisers and microbial transformations of organic nitrogen $(\mathrm{N})$, and also

296 indirectly with nitrogen losses through volatilization, leaching and runoff of N-compounds

297 that are converted into $\mathrm{N}_{2} \mathrm{O}$ off site.

298 Also, the European Commission Joint Research Centre [38], Searchinger et al. [39] and

299 Fargione et al. [40] have all stated that indirect land-use change could potentially release

300 enough greenhouse gases to negate the savings from conventional biofuels. Land use can be 


\section{Please cite this paper as:}

Acquaye et al. (2011) Identification of 'Carbon Hot-Spots' and Quantification of GHG Intensities in the Biodiesel Supply Chain Using Hybrid LCA and Structural Path Analysis. Environ. Sci. Technol., 45 (6), pp 2471-2478

301 defined as the type of activity being carried out on a unit of land and the change in land use

302 can be either direct or indirect. Direct land-use change occurs when feedstock being

303 cultivated for biofuels production (e.g. rapeseed for biodiesel) displaces a prior land use (e.g.

304 forest), thereby generating possible changes in the carbon stock of that land. Indirect land-use change on the other hand occurs when pressure on agriculture due to the displacement of previous activity or use of the biomass induces land-use changes on other land [11].

\subsubsection{Estimation of $\mathrm{N}_{2} \mathrm{O}$ Emissions from Fertiliser Application}

309 The Intergovernmental Panel on Climate Change, IPCC [41] estimate that the direct emission

310 factor associated with $\mathrm{N}_{2} \mathrm{O}$ emissions is likely to be $1 \%$ of the $\mathrm{N}$ applied to the soil. Jungbluth

311 et al. [28] also estimated a direct emissions factor of $1.25 \%$ of the $\mathrm{N}$-input and an indirect

312 emission factor of $2.5 \%$ from the nitrogen that is leached as nitrate. Crutzen et al. [42]

313 however state that global analysis of $\mathrm{N}_{2} \mathrm{O}$ emissions had been previously underestimated and

314 shows that $\mathrm{N}_{2} \mathrm{O}$ emission factor (direct and indirect) in agro-biofuel production is $3-5 \%$ of $\mathrm{N}$

315 applied (that is $0.03-0.05 \mathrm{~kg} \mathrm{~N}_{2} \mathrm{O}-\mathrm{N}(\mathrm{kg} \mathrm{N})^{-1}$. The maximum value of $5 \%$ in Crutzen et al.

316 [42] is used to assess the highest impact case scenario in this study. The minimum value of

$3173 \%$ Crutzen et al. [42] is applied to determine the uncertainty range between the maximum

318 and the minimum impact scenario. Refer to Smeets et al. [43] for additional information on

319 the contribution of $\mathrm{N}_{2} \mathrm{O}$ to the greenhouse gas balance of first-generation biofuels. The

320 fertilizer input rate assumed in this study (137.4 kg-N ha-1 $\mathrm{yr}^{-1}$ ) was used in the JEC - Joint

321 Research Centre-EUCAR-CONCAWE collaboration on biofuel programme [44]. In the

322 cultivation of $1 \mathrm{~kg}$ of rape, the following conditions were assumed: 
Acquaye et al. (2011) Identification of 'Carbon Hot-Spots' and Quantification of GHG Intensities in the Biodiesel Supply Chain Using Hybrid LCA and Structural Path Analysis. Environ. Sci. Technol.,, 45 (6), pp 2471-2478

323 i. Land Use: Transformation from non-irrigated arable land accounted for $71 \%$ of land use at $2.08 \mathrm{~m}^{2}$ per $\mathrm{kg}$ of rape while transformation from pasture and meadow land accounted for $29 \%$ of land use at $0.85 \mathrm{~m}^{2}$ per $\mathrm{kg}$ of rape [45]

ii. Land Occupation: 11 months per year permanent land-use occupation [46].

iii. It was deduced from ecoinvent [28] that $2.6 \mathrm{~kg}$ of rapeseed is required to produce $1 \mathrm{~kg}$ of RME biodiesel

330 The relationship used to determine the life cycle $\mathrm{CO}_{2}$-eq emissions associated with the use of

331 nitrogen fertilizers can be expressed as: Equation 6

$$
\text { Life Cycle Emissions due to } \mathrm{N}_{2} \mathrm{O} \text { Use }=e_{f} y f_{i} r_{s} k_{n}(G W P)_{N_{2} O} \sum_{i=1}^{j} l_{i} p_{i}
$$

332 Where:

$333 e_{f} \quad=\mathrm{N}_{2} \mathrm{O}$ emissions factor $\left[\mathrm{kg} \cdot \mathrm{N}_{2} \mathrm{O}-\mathrm{N}\right.$ per kg-N]

$334 y \quad=$ time between planting and harvest of the bioenergy crop [years]

$335 f_{i}=$ Fertilizer input rate $\left[\mathrm{kg}-\mathrm{N} \mathrm{ha}{ }^{-1} \mathrm{yr}^{-1}\right]$

$336 r_{s} \quad=$ ratio of the $\mathrm{kg}$ of rapeseed to required to produce $1 \mathrm{~kg}$ of RME

$337 \quad k_{n} \quad=$ Factor to convert from $\mathrm{N}_{2} \mathrm{O}-\mathrm{N}$ to $\mathrm{N}_{2} \mathrm{O}$ [equivalent to $\left(\frac{44}{28}\right)$ ]

$338(G W P)_{N_{2} O}=$ Global Warming Potential of $\mathrm{N}_{2} \mathrm{O}$.

$339 l=\quad$ Area of land occupied by bioenergy (biodiesel) crop $\left[\mathrm{m}^{2}\right.$ per $\mathrm{kg}$ of rapeseed $]$

$340 p=$ ratio of the area of particular land type occupied by bioenergy crop to the total area of 341 different land used (in cases where only one land type is used, $p$ will be 1) 
Acquaye et al. (2011) Identification of 'Carbon Hot-Spots' and Quantification of GHG Intensities in the Biodiesel Supply Chain Using Hybrid LCA and Structural Path Analysis. Environ. Sci. Technol.,, 45 (6), pp 2471-2478

343 Using a GWP of 298 for $\mathrm{N}_{2} \mathrm{O}$ and effective land size of $1.723 \mathrm{~m}^{2}$ or $\left(1.723 \times 10^{-4}\right.$ ha $)$ per

$344 \mathrm{~kg}$ of rape seed, it is estimated from Equation 6 that the $\mathrm{N}_{2} \mathrm{O}$ emissions contributed between a

345 high impact scenario of $1.32 \mathrm{~kg} \mathrm{CO}_{2}$-eq per $\mathrm{kg}$ of $\mathrm{RME}$ and a low impact scenario of $0.80 \mathrm{~kg}$

$346 \mathrm{CO}_{2}$-eq per kg of RME biodiesel.

347

348

\subsubsection{Direct and Indirect Land Use Change}

349 The Intergovernmental Panel on Climate Change [47] reports that due to direct land use

350 change, changes in carbon stock per hectare of bioenergy crop cultivation occurs in the

351 following carbon pools for cropland: biomass (above ground biomass and below ground

352 biomass); dead organic matter (dead wood and litter) and soils (soil organic matter). The total

353 change in carbon stock is calculated using Equation 7 below [10].

354 Equation 7:

355

$\Delta$ Carbon Stock Soil $\left[\frac{\mathrm{tC}}{\mathrm{ha}}\right]=\sum_{\mathrm{i}}$ Carbon Stock Change Factor $\left[\frac{\mathrm{tC}}{\mathrm{ha} \cdot \mathrm{yr}}\right] \times \mathrm{T}_{\mathrm{i}}[\mathrm{yr}]$

356 Where

$357 T_{i}=$ time between planting and harvest of the bioenergy crop [years]

358 Based on data on carbon stock change factors for the carbon pools of cropland from the IPCC

359 Guidelines for National Greenhouse Gas Inventories - Agriculture Forestry and other Land

360 Use [47], direct land use change was estimated to be $0.44 \mathrm{~kg} \mathrm{CO}_{2}$-eq per $\mathrm{kg}$ of RME.

361 Indirect land use change (iLUC) is calculated using the theoretical global average indirect

362 land use change factor [48]. In this study it was assumed that the cultivation of rape seed 
Acquaye et al. (2011) Identification of 'Carbon Hot-Spots' and Quantification of GHG Intensities in the Biodiesel Supply Chain Using Hybrid LCA and Structural Path Analysis. Environ. Sci. Technol.,, 45 (6), pp 2471-2478

occurred on $71 \%$ arable and $29 \%$ pasture and meadow land. A 'maximum risk' or 'maximum

iLUC order of magnitude' representing a 75\% share of non-zero risk biofuel is assigned an

iLUC factor of 15 t $\mathrm{CO}_{2}$-eq/ha/yr while a 'low risk' or 'low iLUC order of magnitude' representing $25 \%$ of all non-zero risk biofuels are subject to theoretical full iLUC factor of $5 \mathrm{t}$

$367 \mathrm{CO}_{2}-\mathrm{eq} / \mathrm{ha} / \mathrm{yr}[48]$. The term risk refers to the level of impact due to the conversion of food crop land into bioenergy crop land. A low risk biofuel is therefore assumed to be produced from feedstock cultivated on set-aside or abandoned land. By weighting these iLUC factors according to the ratio of land type and land sizes assumed in the cultivation of rape seed in this study, the iLUC factor used for to the production of $1 \mathrm{~kg}$ of RME biodiesel and its coproducts is estimated to be $11.8 \mathrm{t} \mathrm{CO}_{2}$-eq/ha/yr or $1.86 \mathrm{~kg} \mathrm{CO}_{2}$-eq. Taking into account the allocation factors in Table 2, iLUC is calculated to be $1.22 \mathrm{~kg} \mathrm{CO}_{2}$-eq per $\mathrm{kg}$ of RME.

374 Uncertainty in the impact of land-use change refers to the variability of indirect land-use change factors due to the type of land used in the cultivation of feedstock. Based on the assumptions for maximum/minimum iLUC risk referred to above, the uncertainty range for iLUC for producing $1 \mathrm{~kg}$ of RME biodiesel is estimated to be between of 0.52 to $1.55 \mathrm{~kg} \mathrm{CO}_{2}$ eq.

The emissions associated with all stages of the RME biodiesel production are shown in

380 Figure 1 . The total life cycle $\mathrm{CO}_{2}$-eq emissions for $1 \mathrm{~kg}$ of $\mathrm{RME}$ biodiesel were calculated to 381 be $7.38 \mathrm{~kg} \mathrm{CO}_{2}$-eq or $199 \mathrm{~g} \mathrm{CO}_{2}$-eq/MJ. By accounting for uncertainty in the assessment, it 382 was estimated that the results are in the range 5.03 to $8.44 \mathrm{~kg} \mathrm{CO}_{2}$-eq per $\mathrm{kg}$ of $\mathrm{RME}$ biodiesel. Refer to Figure S5 for normalized results in energy units. 
Acquaye et al. (2011) Identification of 'Carbon Hot-Spots' and Quantification of GHG Intensities in the Biodiesel Supply Chain Using Hybrid LCA and Structural Path Analysis. Environ. Sci. Technol.,, 45 (6), pp 2471-2478

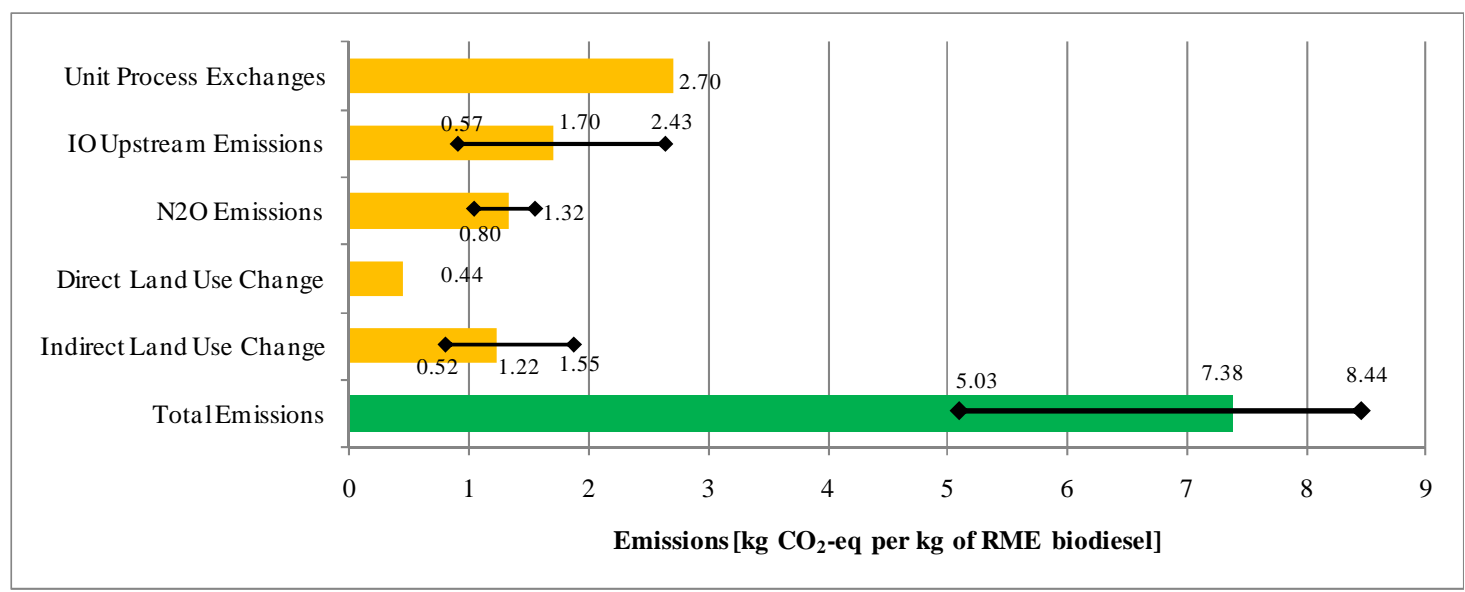

\subsection{Structural Path Analysis and Hotspots of Biodiesel Supply Chain Emissions.}

In Figure S6, the cumulative impacts of sectoral emissions from the higher upstream supply chain paths of biofuel production are presented giving an indication of the relative contribution of each IO sector. These higher upstream supply chain paths represent the IO component of upstream inputs. Seven production layers of RME biodiesel were analysed. It was estimated that the 'Utilities Sector' was the highest sectoral emitter accounting for $172 \mathrm{~g}$ $\mathrm{CO}_{2}$-eq or $44.5 \%$ of total upstream emissions. This was followed by the 'Chemical Sector' emitting $90 \mathrm{~g} \mathrm{CO}_{2}$-eq or $23.3 \%$ of total upstream emissions. As can be seen from Figure S6, the next four sectoral emissions were 'Transportation and Communication' ( $37 \mathrm{~g} \mathrm{CO}_{2}$-eq or 9.6\%), 'Mining' (21 $\mathrm{g} \mathrm{CO}_{2}$-eq or 5.4\%), 'Minerals' (19 $\mathrm{g} \mathrm{CO}_{2}$-eq or 4.8\%) and 'Fuels' $\left(14 \mathrm{~g} \mathrm{CO}_{2}\right.$-eq or $\left.3.7 \%\right)$.

Structural path analysis (SPA) is used to show the inter-connections of various products and industries within the biodiesel supply chain and identify, rank and estimate the $\mathrm{CO}_{2}$-eq of the high emissions intensity paths or 'carbon hot-spots'. 150 of the most important paths of the 
Acquaye et al. (2011) Identification of 'Carbon Hot-Spots' and Quantification of GHG Intensities in the Biodiesel Supply Chain Using Hybrid LCA and Structural Path Analysis. Environ. Sci. Technol.,, 45 (6), pp 2471-2478

401 biodiesel supply chain were extracted in the SPA. The cut-off threshold for individual path

402 contributions was set at $0.05 \%$ of total impacts in the analysis of the supply chain paths.

403 Detailed results for each of the top 50 paths are shown in Table S3 under SI on the web.

404 It was found that $\mathrm{CO}_{2}$-eq emissions impacts on the biodiesel supply chain originate across the 405 entire economy but of the top 150 paths, the majority originate from the sectors 'Other 406 Chemical Products', 'Organic Basic Chemicals', 'Electricity-Coal', 'Distribution and Trade', 407 'Electricity-Gas' and 'Freight transport by Road'.

408 The "hottest spot" or the highest carbon intensity path of the biodiesel upstream supply chain 409 was identified as a path order 1: Rest of World (ROW) Sector (102) 'Other Chemical 410 Products' > Biofuel Process with an estimated $20.7 \mathrm{~g} \mathrm{CO}_{2}$-eq or $5.35 \%$ of the total emissions. 411 This path describes the emissions chain: 'Other Chemical Products' used as an input in the 412 biodiesel production process.

\section{Discussion}

415 The life cycle assessment of the RME biodiesel supply chain estimated the total life cycle 416 emissions of biodiesel production to be $7.38 \mathrm{~kg} \mathrm{CO}_{2}$-eq per $\mathrm{kg}$ with an uncertainty range of 4175.03 to $8.44 \mathrm{~kg} \mathrm{CO}_{2}$-eq per $\mathrm{kg}$. The uncertainty was a result of variability in indirect land use 418 change, $\mathrm{N}_{2} \mathrm{O}$ emissions and IO higher upstream emissions. IO higher upstream emissions 419 accounted for approximately $23 \%$ of total $\mathrm{CO}_{2}$-eq emissions. The use of a hybrid method 420 ensured the integration of process and IO analysis such that higher upstream inputs into 421 sectors such as utilities, transportation, chemicals, mining, services, etc which are normally 


\section{Please cite this paper as:}

Acquaye et al. (2011) Identification of 'Carbon Hot-Spots' and Quantification of GHG Intensities in the Biodiesel Supply Chain Using Hybrid LCA and Structural Path Analysis. Environ. Sci. Technol., 45 (6), pp 2471-2478

422

423

424

425

426

427

428

430

431

432

433

434

435

436

437

438

439

440

441

442

443

excluded from traditional life cycle assessments, are taken into account. In contrast, Halleux et al. [8], Hoefnagels et al. [10] and Kim et al. [49] all undertook life cycle assessments of biofuels using traditional LCA but did not account for upstream emissions outside the process system boundary resulting in the truncation of the product system. Given that some past assessments of biofuels have also neglected the impacts of land use change and $\mathrm{N}_{2} \mathrm{O}$ emissions, assuming that the impacts of land use change, $\mathrm{N}_{2} \mathrm{O}$ emissions and IO upstream emissions cut-offs were truncated from the biofuel product system, as has previously been the case, the total emissions would have been $2.7 \mathrm{~kg} \mathrm{CO}_{2}$-eq per $\mathrm{kg}$. This would have resulted in a $63 \%$ underestimation of the total life cycle emissions. Therefore, IO upstream emissions cut-off, $\mathrm{N}_{2} \mathrm{O}$ emissions and land-use change represent significant impacts which are determinants that can change the environmental profile of the biodiesel supply chain. It was observed that the lack of process-specific data increases uncertainties in life cycle assessments. The uncertainty estimates for this study were based on data variability in indirect land use change, $\mathrm{N}_{2} \mathrm{O}$ emissions from fertiliser application and aggregation of IO data, resulting in the estimation of minimum and maximum carbon impacts of the RME biodiesel supply chain. The estimation of emissions was based on economic allocation between the RME biodiesel supply chain and co-products. This has been recognised as one way of systematically executing allocation in LCA [31-33].

Structural path analysis (SPA) is useful in describing and characterizing carbon hotspots in the supply chain. Specific processes in the RME biodiesel supply chain can be matched to the structural paths in order to identify the hotspots in the supply chain. For example, the first ranked structural path: Other chemical products $>$ Biofuel Process can be identified as the inputs of industrial grade phosphoric acid, $\mathrm{H}_{3} \mathrm{PO}_{4}(85 \%$ in water) into the biodiesel 


\section{Please cite this paper as:}

Acquaye et al. (2011) Identification of 'Carbon Hot-Spots' and Quantification of GHG Intensities in the Biodiesel Supply Chain Using Hybrid LCA and Structural Path Analysis. Environ. Sci. Technol., 45 (6), pp 2471-2478

production process. Likewise, the second ranked structural path: Organic basic chemicals >

446 Biofuel Process describes the inputs of methanol into the biodiesel production process. As

447 can be seen from the ranked structural paths available in the Table S3, all the paths end as a

448 direct input into the RME diesel production process. The demanding sector is therefore

449 responsible for the emissions caused, but the emissions might occur upstream of that sector.

450 For example, in the $12^{\text {th }}$ ranked structural path: UK- Electricity - Coal> UK- Distribution and

451 Trade in Electricity > Biofuel Process; the biodiesel production process is responsible for

452 emitting $3.28 \mathrm{~g} \mathrm{CO}_{2}$-eq per $\mathrm{kg}$ of $\mathrm{RME}$ biodiesel although it occurs upstream of the

453 production process. SPA provides a unique way of identifying processes in the entire supply

454 chain with hot-spots thereby ensuring that appropriate intervention measures and effective 455 policies can be prioritised and implemented to reduce carbon impacts. Emissions resulting

456 from industries in the ROW indicate that biofuel energy policies should not be limited to the

457 UK but rather a holistic approach should be adopted to account for emissions occurring

458 beyond the boundaries of the UK. SPA for co-products was not undertaken since system

459 expansion allocation was not used

460 As has been demonstrated for RME biodiesel, a systematic analysis of hybrid LCA and 461 application of SPA should also be extended to second generation biofuel because the 462 environmental impact of second-generation biofuel production can vary considerably 463 depending on the conversion route as well as the feedstock and site-specific conditions ([50] 464 and [51]). This is because, the benefits of second generation biofuels is being promoted (e.g. 465 [1] and [52]), but the environmental profile is not fully understood. 
Acquaye et al. (2011) Identification of 'Carbon Hot-Spots' and Quantification of GHG Intensities in the Biodiesel Supply Chain Using Hybrid LCA and Structural Path Analysis. Environ. Sci. Technol., 45 (6), pp 2471-2478

467

468

469

470

471

472

473

474

475

476

477

478

479

480

481

482

483

484

485

486

487

488

489

490

491

492

493

494

495

496

497

498

499

500

501

\section{Acknowledgement}

We gratefully acknowledge the financial support provided by the Centre for Low Carbon Future (CLCF), York, UK. The structural path analysis was performed by using the Triple Bottom Line tool developed by the Centre for Integrated Sustainability Analysis (ISA) at the University of Sydney and supplied in the UK by the Centre for Sustainability Accounting (CenSA), York, UK (http://www.bottomline3.co.uk).

\section{Supporting Information Available}

Further tables (unit process exchanges, allocation and SPA results) and figures (biodiesel in the EU, biodiesel hybridised system boundary, results) and spreadsheet of input-output analysis are presented in the Supporting Information.

\section{Literature Cited}

1. European Commission, E., An EU Strategy for Biofuels, COM(2006). 2006, 34 final.

2. van Thuijl, E.; Roos, C.; Beurskens, L. An overview of Biofuel Technologies, Markets And Policies In Europe; 2003

3. Agricultural Commodity Prices EU-27 Oilseeds Production http://www.agricommodityprices.com/futures_prices.php?id=154 (15th June),

4. Food and Agriculture Organization, F. A. O., The State of Food and Agriculture 2008. 2008.

5. European Commission, The impact of a minimum $10 \%$ obligation for biofuel use in the EU-27 in 2020 on agricultural markets. In 2007.

6. Bright, R. M.; Strømman, A. H., Life Cycle Assessment of Second Generation Bioethanols Produced From Scandinavian Boreal Forest Resources. Journal of Industrial Ecology 2009, 13, (4), 514-531.

7. Spiertz, J. H. J.; Ewert, F., Crop production and resource use to meet the growing demand for food, feed and fuel: opportunities and constraints. NJAS - Wageningen Journal of Life Sciences 2009, 56, (4), 281-300.

8. Halleux, H.; Lassaux, S.; Renzoni, R.; Germain, A., Comparative life cycle assessment of two biofuels ethanol from sugar beet and rapeseed methyl ester. The International Journal of Life Cycle Assessment 2008, 13, (3).

9. Ou, X.; Zhang, X.; Chang, S.; Guo, Q., Energy consumption and GHG emissions of six biofuel pathways by LCA in (the) People's Republic of China. Applied Energy 2009, 86, (1). 
Please cite this paper as:

Acquaye et al. (2011) Identification of 'Carbon Hot-Spots' and Quantification of GHG Intensities in the Biodiesel Supply Chain Using Hybrid LCA and Structural Path Analysis. Environ. Sci. Technol., 45 (6), pp 2471-2478

502

503

504

505

506

507

508

509

510

511

512

513

514

515

516

517

518

519

520

521

522

523

524

525

526

527

528

529

530

531

532

533

534

535

536

537

538

539

540

541

542

543

544

545

546
10. Hoefnagels, R.; Smeets, E.; Faaij, A., Greenhouse gas footprints of different biofuel production systems. Renewable and Sustainable Energy Reviews 2010, 14, (7), 1661-1694

11. Gnansounou, E.; Panichelli, L.; Dauriat, A.; Villegas, J. D., Accounting for indirect land-use changes in GHG balances of biofuels: Review of current approaches. Working Paper 2008, REF. 437.101, EPFL.

12. Lenzen, M., Differential Convergence of Life-Cycle Inventories toward Upstream Production Layers. Journal of Industrial Ecology 2002, 6, (3-4), 137-160.

13. Crawford, R. H., Validation of the use of input-output data for embodied energy analysis of the Australian construction industry. Journal of construction research 2005, 6 , (1), 71-90.

14. Rowley, H.; Lundie, S.; Peters, G., A hybrid life cycle assessment model for comparison with conventional methodologies in Australia. The International Journal of Life Cycle Assessment 2009, 14, (6), 508-516.

15. Mattila, T. J.; Pakarinen, S.; Sokka, L., Quantifying the Total Environmental Impacts of an Industrial Symbiosis - a Comparison of Process-, Hybrid and Input-Output Life Cycle Assessment. Environmental Science \& Technology 2010, 44, (11), 4309-4314.

16. Lenzen, M.; Wachsmann, U., Wind turbines in Brazil and Germany: an example of geographical variability in life-cycle assessment. Applied Energy 2004, 77, (2), 119-130.

17. Crawford, R. H., Life cycle energy and greenhouse emissions analysis of wind turbines and the effect of size on energy yield. Renewable and Sustainable Energy Reviews 2009, 13, (9), 2653-2660.

18. Bright, R. M.; Strømman, A. H.; Hawkins, T. R., Environmental Assessment of Wood-Based Biofuel Production and Consumption Scenarios in Norway. Journal of Industrial Ecology 2010, 14, (3), 422-439.

19. Wood, R.; Lenzen, M., Structural path decomposition. Energy Economics 2009, 31, (3), 335-341.

20. Baboulet, O.; Lenzen, M., Evaluating the environmental performance of a university. Journal of Cleaner Production 2010, 18, (12), 1134-1141.

21. Suh, S.; Huppes, G., Methods for Life Cycle Inventory of a product. Journal of Cleaner Production 2005, 13, (7), 687-697.

22. Heijungs, R.; de Koning, A.; Suh, S.; Huppes, G., Toward an Information Tool for Integrated Product Policy: Requirements for Data and Computation. Journal of Industrial Ecology 2006, 10, (3), 147-158.

23. Strømman, A. H.; Peters, G. P.; Hertwich, E. G., Approaches to correct for double counting in tiered hybrid life cycle inventories. Journal of Cleaner Production 2009, 17, (2), 248-254.

24. Department for Business Enterprise and Regulatory Reform Energy Trends; 2007; pp $1-76$.

25. Lenzen, M.; Crawford, R., The Path Exchange Method for Hybrid LCA. Environmental Science \& Technology 2009, 43, (21), 8251-8256.

26. Peters, G. P.; Hertwich, E. G., Structural analysis of international trade: Environmental impacts of Norway. Economic Systems Research 2006, 18, (2), 155 - 181.

27. Huang, Y. A.; Lenzen, M.; Weber, C. L.; Murray, J.; Matthews, H. S., The role of input-output analysis for the screening of corporate carbon footprints. Economic Systems Research 2009, 21, (3), 217-242. 
Acquaye et al. (2011) Identification of 'Carbon Hot-Spots' and Quantification of GHG Intensities in the Biodiesel Supply Chain Using Hybrid LCA and Structural Path Analysis. Environ. Sci. Technol., 45 (6), pp 2471-2478

28. Jungbluth, N.; Chudacoff, M.; Dauriat, A.; Dinkel, F.; Doka, G.; Faist Emmenegger, M.; Gnansounou, E.; Kljun, N.; Schleiss, K.; Spielmann, M.; Stettler, C.; Sutter, J. Lifecycle Inventories of Bioenergy.ecoinvent report No. 17; Dubendorf, Switzerland, 2007.

29. Wiedmann, T.; Wood, R.; Lenzen, M.; Minx, J.; Guan, D.; Barrett, J. Development of an Embedded Carbon Emissions Indicator - Producing a Time Series of Input-Output Tables and Embedded Carbon Dioxide Emissions for the UK by Using a MRIO Data Optimisation System. Final Report to the Department for Environment, Food and Rural Affairs by Stockholm Environment Institute at the University of York and Centre for Integrated Sustainability Analysis at the University of Sydney.; Project Ref.: EV02033; Defra: London, UK, July 2008, 2008.

30. Wiedmann, T.; Barrett, J. A Greenhouse Gas Footprint Analysis of UK Central Government, 1990-2008: Report to the UK Department for Environment, Food and Rural Affairs by the Centre for Sustainability Accounting; London, UK, 30 November 2010, 2010; pp 1-41.

31. Guinée, J. B.; Heijungs, R.; Huppes, G., Economic Allocation: Examples and Derived Decision Tree. Int J LCA 2004, 9, (1), 23 - 33.

32. Huppes, G., Macro-environmental policy - principles and design. Elsevier: Amsterdam, 1993.

33. Guinée, J., Handbook on life cycle assessment. Operational guide to the ISO. Kluwer Academic Publishing: 2002.

34. International Standard Organisation, I. ISO 14041: Environmental management Lifecycle assessment - Goal and scope definition and Inventory analysis; Geneva, 1998.

35. Reijnders, L., The life cycle emission of greenhouse gases associated with plant oils used as biofuel. Renewable Energy 2011, 36, (2), 879-880.

36. Miller, S. A., Minimizing Land Use and Nitrogen Intensity of Bioenergy. Environmental Science \& Technology 2010, 44, (10), 3932-3939.

37. Intergovernmental Panel on Climate Change, I., Climate change 2007: the physical science basis. Contribution of working group I to the fourth assessment report of the Intergovernmental Panel on Climate Change,. S. Solomon, D. Qin, M. Manning, Z. Chen, $M$. Marquis, K.B. Averyt, M. Tignor, H.L. Miller (eds) 2007, Cambridge, UK and New York: Cambridge University Press.

38. European Commission Joint Research Centre Biofuels in the European Context: Facts and Uncertainties; 2008, 2008.

39. Searchinger, T.; Heimlich, R.; Houghton, R. A.; Dong, F.; Elobeid, A.; Fabiosa, J.; Tokgoz, S.; Hayes, D.; Yu, T.-H., Use of U.S. Croplands for Biofuels Increases Greenhouse Gases Through Emissions from Land-Use Change. Science 2008, 319, (5867), 1238-1240.

40. Fargione, J.; Hill, J.; Tilman, D.; Polasky, S.; Hawthorne, P., Land Clearing and the Biofuel Carbon Debt. Science 2008, 319, (5867), 1235-1238.

41. Intergovernmental Panel on Climate Change, I. N2O emissions from managed soils, and $\mathrm{CO} 2$ emissions from lime and urea application; 2006; pp 1--54.

42. Crutzen, P. J.; Mosier, A. R.; Smith, K. A.; Winiwarter, W., N2O release from agrobiofuel production negates global warming reduction by replacing fossil fuels. Atmos. Chem. Phys. Discuss. 2007, 7, (4), 11191-11205.

43. Smeets, E. M. W.; Bouwman, L. F.; Stehfest, E.; Van Vuuren, D. P.; Posthuma, A., Contribution of $\mathrm{N} 2 \mathrm{O}$ to the greenhouse gas balance of first-generation biofuels. Global Change Biology 2009, 15, (3), 780-780. 
Acquaye et al. (2011) Identification of 'Carbon Hot-Spots' and Quantification of GHG Intensities in the Biodiesel Supply Chain Using Hybrid LCA and Structural Path Analysis. Environ. Sci. Technol., 45 (6), pp 2471-2478

593 44. JEC - Joint Research Centre-EUCAR-CONCAWE collaboration, JEC Biofuels 594 Programme -WTW results VERSION 3. In 2008; p ROFX_HY.

595 45. Ecoinvent Lifecycle Inventories of Bioenergy; 2007.

596 46. Nemecek, T.; Heil, A.; Huguenin, O.; Meier, S.; Erzinger, S.; Blaser, S.; Dux, D.;

597 Zimmermmann, A., Lifecyle Inventories of Agriculture Production Systems. In Swiss Centre 598 for Lifecycle Inventories: 2007; Vol. Ecoinvent Report Number 15.

599 47. Intergovernmental Panel on Climate Change 2006 IPCC Guidelines for National 600 Greenhouse Gas Inventories: Vol 4, Chapter 5; 2006.

601 48. Institute of Applied Ecology Bioenergy GHG Emission Balances including Direct and

602 Indirect Uand Change Effects.

603 http://www.bioenergytrade.org/downloads/bru07indirectlucfritzsche.pdf

604 49. Kim, H.; Kin, S.; Dale, B., Biofuels, Land Use Change, and Greenhouse Gas

605 Emissions: Some Unexplored Variables. Environ. Sci. Technol. 2009, 43, 961-967.

606 50. International Energy Agency Sustainable Production of Second-Generation Biofuels;

607 Potential and perspectives in major economies and developing countries; 2010.

608 51. European Commission Biofuel-the Way Forward; 2008.

609 52. OECD Observer, Biofuel: A Second Chance. 2010.

610

611

612 
Acquaye et al. (2011) Identification of 'Carbon Hot-Spots' and Quantification of GHG Intensities in the Biodiesel Supply Chain Using Hybrid LCA and Structural Path Analysis. Environ. Sci. Technol., 45 (6), pp 2471-2478

\section{Supporting Information (Environmental Science and Technology):}

\section{Identification of 'Carbon Hot-Spots' and Quantification of GHG Intensities in the Biodiesel Supply Chain using Hybrid LCA and}

\section{Structural Path Analysis}

First Author and Corresponding Author

ADOLF A. ACQUAYE

Stockholm Environment Institute, University of York, Grimston House, York, YO10 5DD, UK

Tel.: +441904322893; Fax: +441904322898; Email: adolf.acquaye@york.ac.uk

Figure S1: Timeline of Policies affecting Biofuel Production in Europe

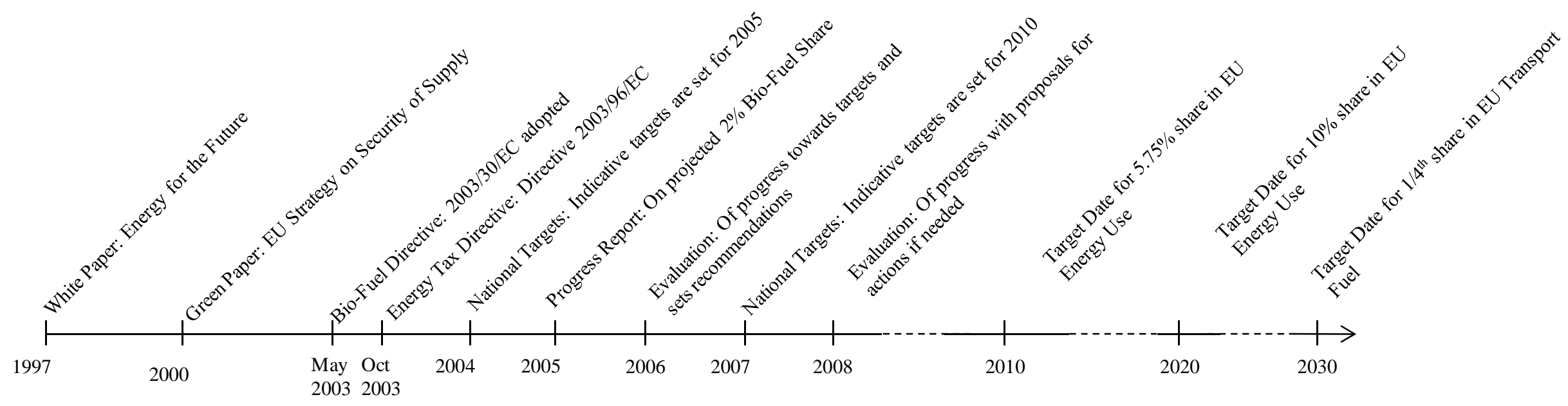




\section{Please cite this paper as:}

Acquaye et al. (2011) Identification of 'Carbon Hot-Spots' and Quantification of GHG Intensities in the Biodiesel Supply Chain Using Hybrid LCA and Structural Path Analysis. Environ. Sci. Technol., , 45 (6), pp 2471-2478

Figure S2: Trend in the growth of Biodiesel in Europe (Adapted from statistics of the European Biodiesel Board, 2009)

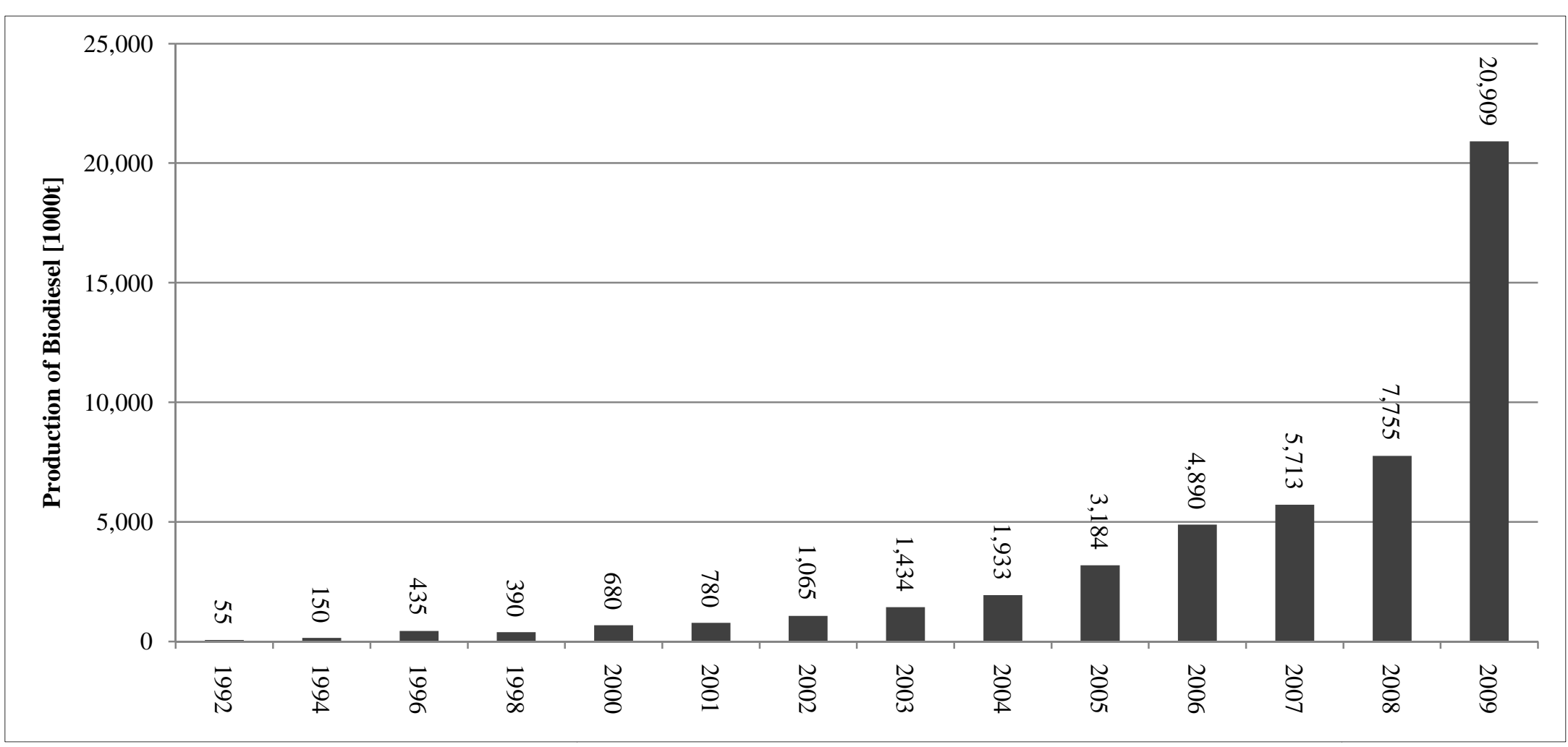

Reference: European Biodiesel Board, 2009. "Statistics: The EU Biodiesel Industry". Adapted from: http://www.ebb-eu.org/stats.php\# 
Acquaye et al. (2011) Identification of 'Carbon Hot-Spots' and Quantification of GHG Intensities in the Biodiesel Supply Chain Using Hybrid LCA and Structural Path Analysis. Environ. Sci. Technol., 45 (6), pp 2471-2478

Figure S3: Depiction of the Hybridised Systems Approach to GHG Assessment of Biodiesel Supply Chain used in this study

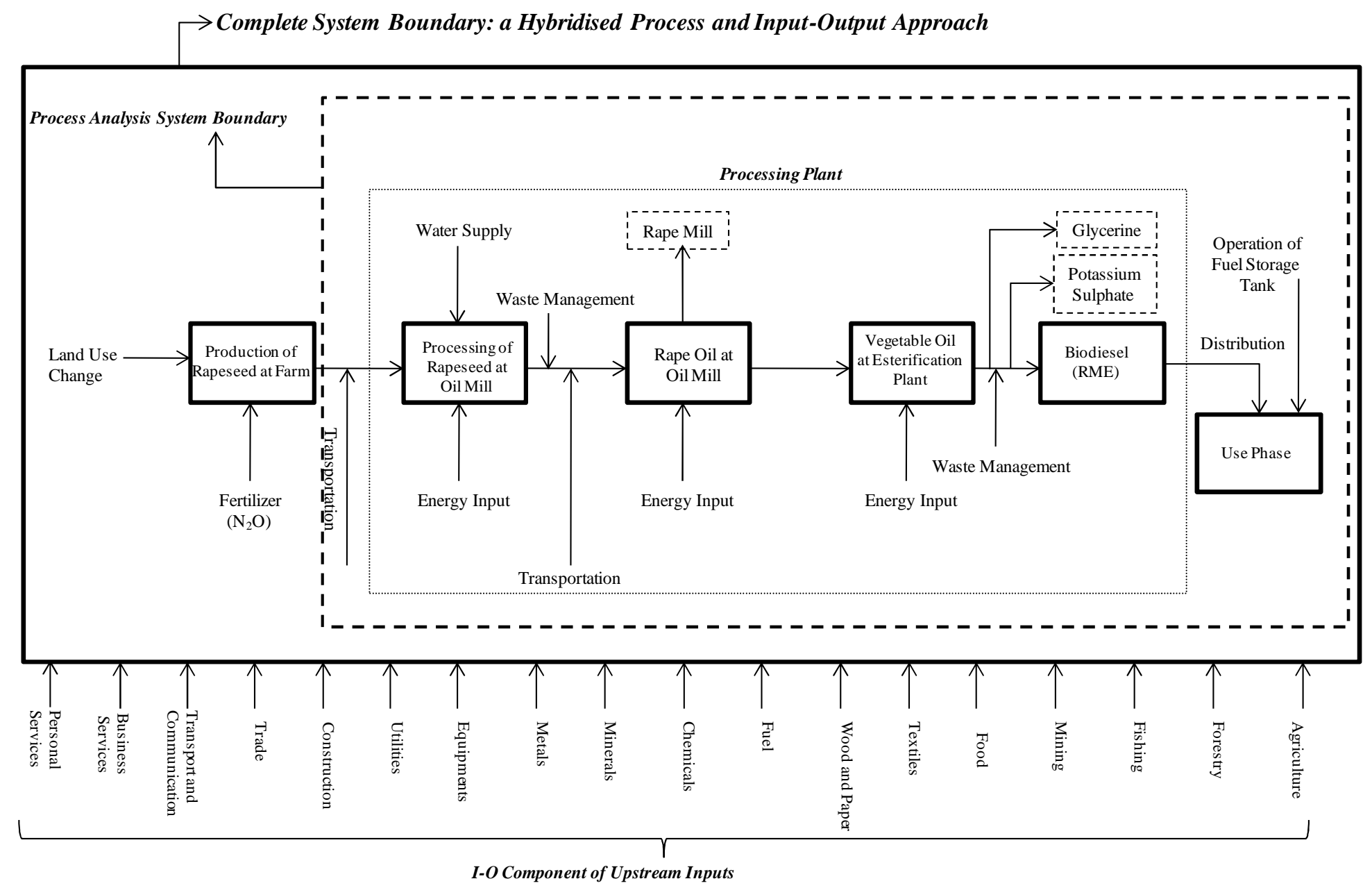


Acquaye et al. (2011) Identification of 'Carbon Hot-Spots' and Quantification of GHG Intensities in the Biodiesel Supply Chain Using Hybrid LCA and Structural Path Analysis. Environ. Sci. Technol., 45 (6), pp 2471-2478

Figure S4: Simplified representation of Structural Path Analysis of two products used in the process of producing biodiesel

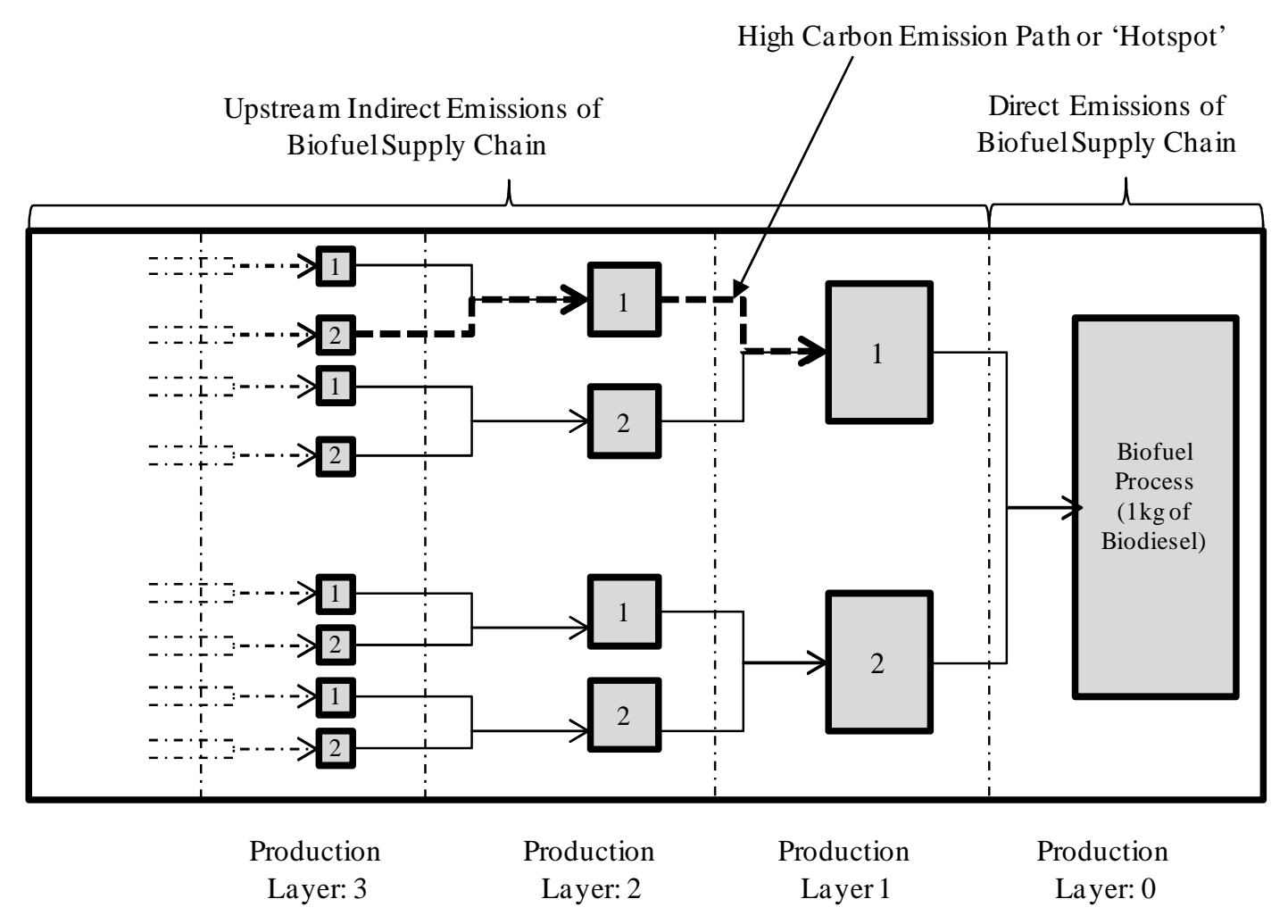


Acquaye et al. (2011) Identification of 'Carbon Hot-Spots' and Quantification of GHG Intensities in the Biodiesel Supply Chain Using Hybrid LCA and Structural Path Analysis. Environ. Sci. Technol., 45 (6), pp 2471-2478

Figure S5: Life Cycle Emissions of RME Production and Supply Chain normalized in energy units

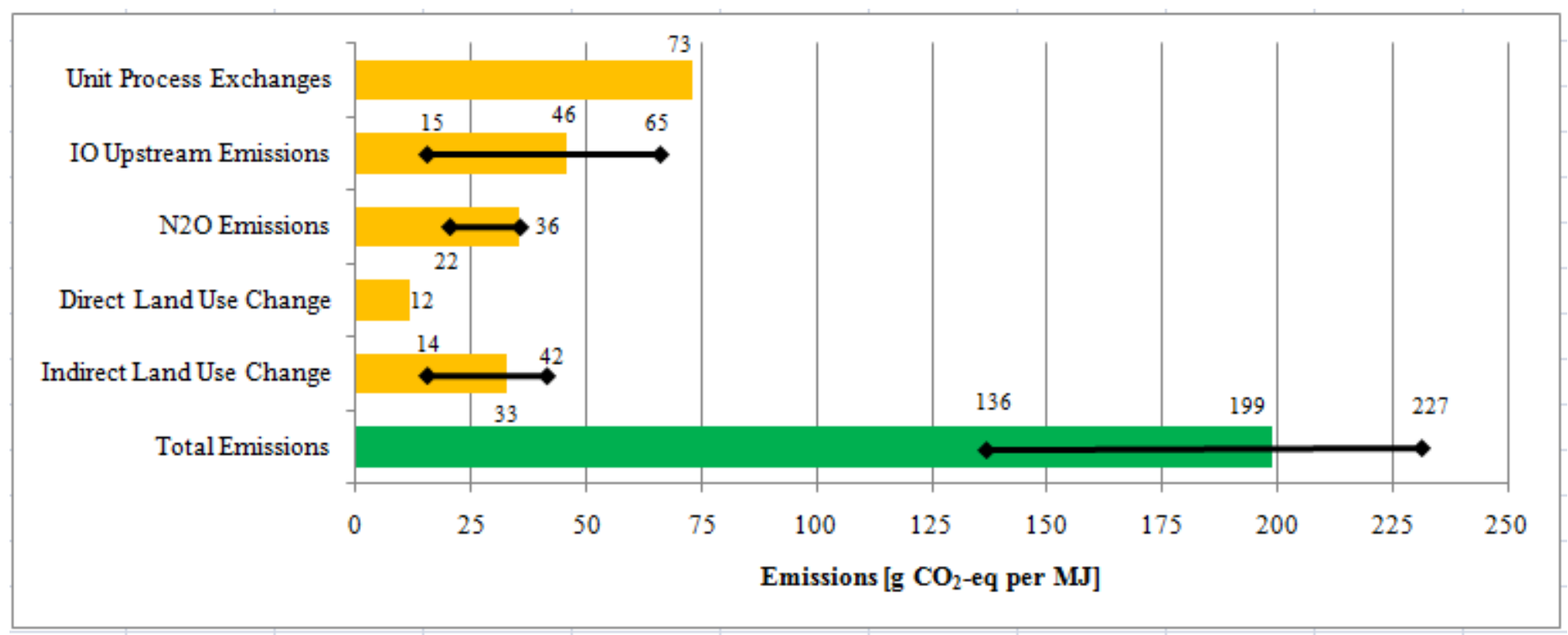


Acquaye et al. (2011) Identification of 'Carbon Hot-Spots' and Quantification of GHG Intensities in the Biodiesel Supply Chain Using Hybrid LCA and Structural Path Analysis. Environ. Sci. Technol., 45 (6), pp 2471-2478

Figure S6: Depiction of build-up of environmental impact along higher upstream production layers in the biodiesel supply chain. The contributions of main sections of the economy are shown.

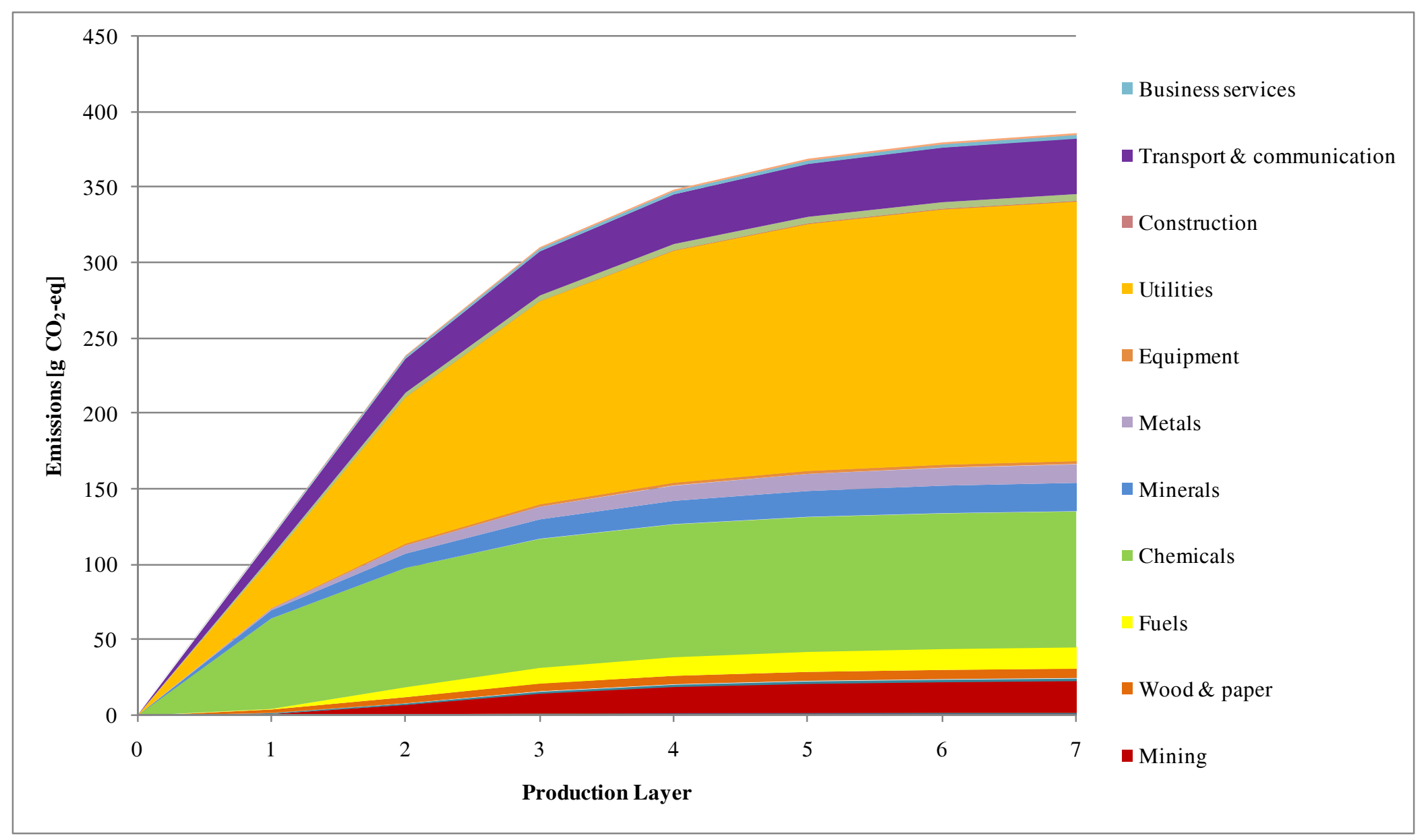




\section{Please cite this paper as:}

Acquaye et al. (2011) Identification of 'Carbon Hot-Spots' and Quantification of GHG Intensities in the Biodiesel Supply Chain Using Hybrid LCA and Structural Path Analysis. Environ. Sci. Technol., 45 (6), pp 2471-2478

Table S1: Description of Unit Process Exchanges for biodiesel supply chain

\begin{tabular}{|c|c|}
\hline Unit Process Exchanges & Description \\
\hline $\begin{array}{l}\text { Biomass/Fuels: rape methyl ester production at esterification } \\
\text { plant }\end{array}$ & $\begin{array}{l}\text { The process includes the esterification process of oil to methyl ester, glycerine and potassium } \\
\text { sulphate, intermediate storage of the oil and products, treatment of specific wastewater effluents. } \\
\text { System boundary is at the esterification plant. }\end{array}$ \\
\hline Electricity/Supply Mix: low voltage electricity generation at grid & $\begin{array}{l}\text { Data set includes the transmission network infrastructure and emissions from transmission at low } \\
\text { voltage }\end{array}$ \\
\hline $\begin{array}{l}\text { Oil/Heating System: light fuel oil burnt in } 100 \mathrm{~kW} \text { non- } \\
\text { modulating boiler }\end{array}$ & $\begin{array}{l}\text { Processes include electricity use, waste and direct air emissions from combustion in the operation } \\
\text { of operation of a light fuel oil boiler }\end{array}$ \\
\hline Transportation Systems/Trains: transport, freight, rail & $\begin{array}{l}\text { Inventory refers to the entire transport life cycle including production, maintenance and disposal, } \\
\text { construction and maintenance and disposal of railway tracks. }\end{array}$ \\
\hline $\begin{array}{l}\text { Transportation System: transport, lorry }>16 \mathrm{t} \text { fleet average and } \\
\text { transport, lorry } 20-28 \mathrm{t} \text {, fleet average }\end{array}$ & $\begin{array}{l}\text { Inventory refers to the entire transport life cycle: operation of vehicle; production, maintenance and } \\
\text { disposal of vehicles; construction and maintenance and disposal of road }\end{array}$ \\
\hline Water supply/production: tap water, at user & Infrastructure and energy use for water treatment and transportation to the end user \\
\hline $\begin{array}{l}\text { Waste management/hazardous waste incineration: disposal, } \\
\text { separator sludge, } 90 \% \text { water, to hazardous waste incineration }\end{array}$ & $\begin{array}{l}\text { Waste-specific air and water emissions from incineration, auxiliary material consumption for flue } \\
\text { gas cleaning. Short-term emissions to river water and long-term emissions to ground water from } \\
\text { residual material landfill (from solidified fly ashes and scrubber sludge). Process energy demands } \\
\text { for hazardous waste incineration }\end{array}$ \\
\hline $\begin{array}{l}\text { Waste management/sanitary landfill: disposal, municipal solid } \\
\text { waste, } 22.9 \% \text { water, to sanitary landfill }\end{array}$ & $\begin{array}{l}\text { Waste-specific short-term emissions to air via landfill gas incineration and landfill leachate. Burdens } \\
\text { from treatment of short-term leachate }(0-100 a) \text { in wastewater treatment plant }\end{array}$ \\
\hline $\begin{array}{l}\text { Waste management/wastewater treatment: class } 2 \text { wastewater } \\
\text { treatment of rainwater from mineral oil storage and class } 2 \\
\text { wastewater treatment of sewage }\end{array}$ & $\begin{array}{l}\text { Infrastructure materials for municipal wastewater treatment plant transport, dismantling. Land use } \\
\text { burdens }\end{array}$ \\
\hline
\end{tabular}




\section{Please cite this paper as:}

Acquaye et al. (2011) Identification of 'Carbon Hot-Spots' and Quantification of GHG Intensities in the Biodiesel Supply Chain Using Hybrid LCA and Structural Path Analysis. Environ. Sci. Technol., , 45 (6), pp 2471-2478

Oil/Production: regional distribution, oil products

Infrastructure (materials and land use) for storage tanks and petrol stations. Bottom-Up estimation based on plant data. Life time is 80 years. Product storage volume of storage tanks is $10,000 \mathrm{~m}^{3}$ with

Table S2: Allocation Factor of RME Production Processes (Adapted from [24])

\begin{tabular}{l|l|l}
\hline Production Stage & Products & Allocation Factor (\%) \\
\hline Oil Mill & Rape Oil & 75.4 \\
& Oil Mill & 24.6 \\
\hline Esterification Plant & Rape Methyl Ester & 86.9 \\
& Glycerine & 12.9 \\
& Potassium Phosphate & 0.2 \\
\hline
\end{tabular}


Acquaye et al. (2011) Identification of 'Carbon Hot-Spots' and Quantification of GHG Intensities in the Biodiesel Supply Chain Using Hybrid LCA and Structural Path Analysis. Environ. Sci. Technol., 45 (6), pp 2471-2478

Table S3: Top-50 of the Ranked Structural Paths contributing to RME Biodiesel Upstream Supply Chain Emissions (UK = United Kingdom, ROW = Rest of World; see Supporting Spreadsheet S1 for numbering of sectors)

\begin{tabular}{|c|c|c|c|c|}
\hline Rank & Supply Chain Path Description of RME Biodiesel & $\begin{array}{l}\text { Path value } \\
{\left[\mathrm{g} \mathrm{CO}_{2} \text {-eq] }\right.}\end{array}$ & $\begin{array}{l}\text { Path } \\
\text { Order }\end{array}$ & $\begin{array}{l}\text { Percentage in } \\
\text { Total Impact }\end{array}$ \\
\hline 1 & ROW-102 Other chemical products > Biofuel Process & 20.70 & 1 & $5.35 \%$ \\
\hline 2 & ROW-95 Organic basic chemicals $>$ Biofuel Process & 19.70 & 1 & $5.10 \%$ \\
\hline 3 & UK-151 Electricity - coal > Biofuel Process & 17.00 & 1 & $4.41 \%$ \\
\hline 4 & ROW-161 Distribution and trade in electricity in electricity $>$ ROW-102 Other chemical products $>$ Biofuel Process & 9.52 & 2 & $2.46 \%$ \\
\hline 5 & ROW-161 Distribution and trade in electricity in electricity > ROW-95 Organic basic chemicals > Biofuel Process & 9.09 & 2 & $2.35 \%$ \\
\hline 6 & UK-152 Electricity - gas > Biofuel Process & 6.59 & 1 & $1.71 \%$ \\
\hline 7 & UK-182 Freight transport by road > Biofuel Process & 5.56 & 1 & $1.44 \%$ \\
\hline 8 & ROW-97 Plastics and synthetic rubber $>$ Biofuel Process & 4.65 & 1 & $1.20 \%$ \\
\hline 9 & UK-186 Passenger air transport > Biofuel Process & 3.46 & 1 & $0.90 \%$ \\
\hline 10 & UK-116 Aluminium > Biofuel Process & 3.39 & 1 & $0.88 \%$ \\
\hline 11 & UK-97 Plastics and synthetic rubber > Biofuel Process & 3.38 & 1 & $0.87 \%$ \\
\hline 12 & UK-151 Electricity - coal > UK-161 Distribution and trade in electricity > Biofuel Process & 3.28 & 2 & $0.85 \%$ \\
\hline 13 & ROW-94 Inorganic basic chemicals > Biofuel Process & 2.75 & 1 & $0.71 \%$ \\
\hline 14 & ROW-160 Transmission of electricity $>$ ROW-102 Other chemical products > Biofuel Process & 2.33 & 2 & $0.60 \%$ \\
\hline 15 & ROW-160 Transmission of electricity $>$ ROW-95 Organic basic chemicals $>$ Biofuel Process & 2.23 & 2 & $0.58 \%$ \\
\hline 16 & ROW-161 Distribution and trade in electricity $>$ ROW-97 Plastics and synthetic rubber $>$ Biofuel Process & 2.15 & 2 & $0.56 \%$ \\
\hline 17 & UK-94 Inorganic basic chemicals > Biofuel Process & 1.84 & 1 & $0.48 \%$ \\
\hline
\end{tabular}




\section{Please cite this paper as:}

Acquaye et al. (2011) Identification of 'Carbon Hot-Spots' and Quantification of GHG Intensities in the Biodiesel Supply Chain Using Hybrid LCA and Structural Path Analysis. Environ. Sci. Technol., 45 (6), pp 2471-2478

\begin{tabular}{|c|c|c|c|c|}
\hline 18 & UK-170 Wholesale trade > Biofuel Process & 1.80 & 1 & $0.47 \%$ \\
\hline 19 & ROW-152 Electricity - gas $>$ ROW-102 Other chemical products $>$ Biofuel Process & 1.73 & 2 & $0.45 \%$ \\
\hline 20 & UK-152 Electricity - gas > UK-162 Gas distribution > Biofuel Process & 1.72 & 1 & $0.44 \%$ \\
\hline 21 & ROW-152 Electricity - gas $>$ ROW-95 Organic basic chemicals $>$ Biofuel Process & 1.65 & 2 & $0.43 \%$ \\
\hline 22 & ROW-151 Electricity - coal > ROW-102 Other chemical products > Biofuel Process & 1.46 & 2 & $0.38 \%$ \\
\hline 23 & ROW-151 Electricity - coal > ROW-95 Organic basic chemicals > Biofuel Process & 1.39 & 2 & $0.36 \%$ \\
\hline 24 & UK-80 Articles of paper > Biofuel Process & 1.32 & 1 & $0.34 \%$ \\
\hline 25 & ROW-105 Plastic plates, sheets $>$ ROW-102 Other chemical products $>$ Biofuel Process & 1.25 & 2 & $0.32 \%$ \\
\hline 26 & ROW-161 Distribution and trade in electricity > ROW-94 Inorganic basic chemicals > Biofuel Process & 1.24 & 2 & $0.32 \%$ \\
\hline 27 & UK-152 Electricity - gas > UK-161 Distribution and trade in electricity > Biofuel Process & 1.24 & 2 & $0.32 \%$ \\
\hline 28 & ROW-105 Plastic plates, sheets $>$ ROW-95 Organic basic chemicals $>$ Biofuel Process & 1.20 & 2 & $0.31 \%$ \\
\hline 29 & UK-182 Freight transport by road > UK-170 Wholesale trade > Biofuel Process & 1.13 & 2 & $0.29 \%$ \\
\hline 30 & ROW-95 Organic basic chemicals > UK-97 Plastics and synthetic rubber > Biofuel Process & 1.10 & 2 & $0.28 \%$ \\
\hline 31 & ROW-105 Plastic plates, sheets > Biofuel Process & 1.04 & 1 & $0.27 \%$ \\
\hline 32 & UK-105 Plastic plates, sheets > Biofuel Process & 1.01 & 1 & $0.26 \%$ \\
\hline 33 & ROW-100 Pharmaceuticals $>$ ROW-102 Other chemical products $>$ Biofuel Process & 1.00 & 2 & $0.26 \%$ \\
\hline 34 & ROW-100 Pharmaceuticals $>$ ROW-95 Organic basic chemicals $>$ Biofuel Process & 0.96 & 2 & $0.25 \%$ \\
\hline 35 & UK-95 Organic basic chemicals > Biofuel Process & 0.90 & 1 & $0.23 \%$ \\
\hline 36 & ROW-154 Electricity - nuclear > ROW-102 Other chemical products > Biofuel Process & 0.90 & 2 & $0.23 \%$ \\
\hline 37 & ROW-154 Electricity - nuclear > ROW-95 Organic basic chemicals > Biofuel Process & 0.86 & 2 & $0.22 \%$ \\
\hline 38 & UK-151 Electricity - coal > UK-161 Distribution and trade in electricity > UK-162 Gas distribution > Biofuel Process & 0.84 & 3 & $0.22 \%$ \\
\hline 39 & UK-151 Electricity - coal > UK-162 Gas distribution > Biofuel Process & 0.81 & 2 & $0.21 \%$ \\
\hline 40 & UK-157 Electricity by biomass > Biofuel Process & 0.79 & 1 & $0.20 \%$ \\
\hline
\end{tabular}




\section{Please cite this paper as:}

Acquaye et al. (2011) Identification of 'Carbon Hot-Spots' and Quantification of GHG Intensities in the Biodiesel Supply Chain Using Hybrid LCA and Structural Path Analysis. Environ. Sci. Technol., , 45 (6), pp 2471-2478

\begin{tabular}{|c|c|c|c|c|}
\hline 41 & ROW-161 Distribution and trade in electricity > Biofuel Process & 0.75 & 1 & $0.19 \%$ \\
\hline 42 & ROW-85 Motor spirit (gasoline) $>$ ROW-102 Other chemical products $>$ Biofuel Process & 0.71 & 2 & $0.18 \%$ \\
\hline 43 & UK-180 Taxi operation > Biofuel Process & 0.69 & 1 & $0.18 \%$ \\
\hline 44 & UK-177 Inter-city coach sevice > Biofuel Process & 0.68 & 1 & $0.18 \%$ \\
\hline 45 & ROW-85 Motor spirit (gasoline) $>$ ROW-95 Organic basic chemicals $>$ Biofuel Process & 0.68 & 2 & $0.18 \%$ \\
\hline 46 & UK-151 Electricity - coal > UK-162 Gas distribution > Biofuel Process & 0.67 & 1 & $0.17 \%$ \\
\hline 47 & ROW-188 Supporting and auxiliary transport $>$ ROW-102 Other chemical products $>$ Biofuel Process & 0.62 & 2 & $0.16 \%$ \\
\hline 48 & ROW-113 Articles of concrete $>$ ROW-102 Other chemical products $>$ Biofuel Process & 0.60 & 2 & $0.16 \%$ \\
\hline 49 & UK-95 Organic basic chemicals. > UK-97 Plastics and synthetic rubber > Biofuel Process & 0.59 & 1 & $0.15 \%$ \\
\hline 50 & ROW-188 Supporting and auxiliary $>$ ROW-95 Organic basic chemicals $>$ Biofuel Process & 0.59 & 2 & $0.15 \%$ \\
\hline
\end{tabular}

